\title{
Bactericidal/Permeability-Increasing Protein Inhibits Induction of Macrophage Nitric Oxide Production by Lipopolysaccharide
}

\author{
Sally Betz Corradin, Didier Heumann, Philippe Gallay, \\ Josiane Smith, Jacques Mauël, \\ and Michel Pierre Glauser
}

Institute of Biochemistry. University of Lausanne, Epalinges, and Division of Infectious Diseases, Department of Medicine. CHUV.

Lausanne, Switzerland

\begin{abstract}
A recombinant (r) $\mathrm{NH}_{2}$-terminal fragment of bactericidal/permeability-increasing protein, $\mathrm{rBPI}_{23}$, was shown to inhibit murine macrophage nitric oxide (NO) production elicited by lipopolysaccharide (LPS) plus interferon- $\gamma$ (IFN- $\gamma$ ). Normal mouse plasma amplified NO synthesis (measured as $\mathrm{NO}_{2}^{-}$release) at $\mathrm{LPS}$ concentrations of $1-10 \mathrm{ng} / \mathrm{mL}$, and antibody to the plasma LPS-binding protein (LBP) partially inhibited $\mathrm{NO}_{2}^{-}$release in the presence of normal mouse plasma. $\mathrm{rBPI}_{23}(1 \mu \mathrm{g} / \mathrm{mL})$ effectively inhibited LPS-dependent $\mathrm{NO}_{2}^{-}$release in the presence or absence of normal mouse plasma. Fifty percent inhibition of IFN- $\gamma /$ LPS-elicited $\mathrm{NO}_{2}^{-}$production or of binding of fluoresceinated LPS was obtained with $\sim 0.2 \mu \mathrm{g} / \mathrm{mL} \mathrm{rBPI}_{23}$. These results provide a basis for studies of $\mathrm{rBPI}_{23}$ effects on NO synthase activity in murine models of gramnegative sepsis.
\end{abstract}

Lipopolysaccharide (LPS), either as part of the outer membrane of gram-negative bacteria or when released into the circulation upon bacterial lysis, is a potent stimulus of macrophage cytokine production and mediator release $[1,2]$. Despite extensive investigation, the precise mechanism(s) by which LPS stimulates macrophage function is still unknown. Recently, a plasma protein, LPS-binding protein (LBP), was shown to bind to smooth and rough LPS [3-5]. Macrophage cell surface protein CDI 4 was subsequently shown to recognize the LBP-LPS complex [6], and several studies have now demonstrated dramatic enhancement of both binding of and functional responses to LPS by purified LBP [6-11]. Furthermore, transfection of cDNA encoding CDI4 into a murine pre-B lymphocyte cell line, which does not normally express this gene, strongly increased the sensitivity of those cells to low concentrations of LPS in the presence of LBP [12]. Although such results do not imply that CDI4 alone can initiate signal transduction, they provide evidence for an important role of LBP in modifying host responses to LPS.

Another LPS-binding protein, the neutrophil granule bactericidal/permeability-increasing protein (BPI), binds to LPS in the outer membrane of gram-negative bacteria, causing permeability and cell death [13-16]. Although BPI shows striking sequence homology to LBP [7, 17], the two proteins exert different effects on LPS activity. BPI, its $\mathrm{NH}_{2}$-terminal

Received 13 April 1993: revised 7 September 1993.

Grant support: Swiss National Fund for Scientific Research (31-30857.91 and 32-30265.90) and XOMA (Berkeley. CA). S.B.C. is a Max Cloetta fellowship recipient.

Reprints or correspondence: Dr. Sally Betz Corradin. Institute of Biochemistry, University of Lausanne, Chemin des Boveresses 155, 1066 Epalinges, Switzerland.

The Journal of Infectious Diseases 1994:169:105-11 (c) 1994 by The University of Chicago. All rights reserved. $0022-1899 / 94 / 6901-0015 \$ 01.00$ fragment, and recombinant (r) BPI inhibit LPS activity in various in vitro systems, including activation of limulus amebocyte lysate [18], priming for neutrophil leukotriene release [18] or LPS-elicited complement receptor expression [19], and induction of tumor necrosis factor (TNF) secretion by human monocytes $[18,20]$. Recently, a recombinant protein, $\mathrm{rBPI}_{23}$, corresponding to the amino-terminal region of human BPI was produced and purified [21]. $\mathrm{rBPI}_{23}$ showed high affinity binding to lipid $A$ and various types of LPS and LPS-neutralizing activity $[16,22]$. We have recently demonstrated that $\mathrm{rBPI}_{23}$ inhibits the plasma-mediated binding of LPS to human monocytes in a dose-dependent manner [23]. Moreover, antibody to murine LBP inhibited LPS binding in normal mouse plasma (NMP) [1 1, 23], suggesting that binding occurs through the CDI4/LBP pathway and that $\mathrm{rBPI}_{23}$ must compete with LBP to be an efficient inhibitor of LPS.

Although certain macrophage responses such as TNF $\alpha$ secretion occur with LPS alone, other activities, including the induction of cytotoxic activity toward tumor cells or intracellular pathogens and synthesis of nitric oxide (NO), are greatly enhanced by costimulation of LPS with interferon- $\gamma$ $(\mathrm{IFN}-\gamma)$ [24-27]. $\mathrm{NO}$ and its stable derivatives $\mathrm{NO}_{2}^{-}$and $\mathrm{NO}_{3}^{-}$are derived from $\mathrm{L}$-arginine via the action of a group of enzymes termed NO synthases $[28,29]$. The constitutive isoenzyme present in endothelial and neuronal cells is reversibly regulated by free calcium ions and can rapidly generate small amounts of NO. Moreover, a cytokine-inducible NO synthase, most extensively studied in murine macrophages, is a calcium-independent enzyme capable of producing much higher levels of $\mathrm{NO}$ over a prolonged period. Although constitutive production of NO is believed to play a role in the maintenance of vascular tone, increased production or indiscriminate release occurring on activation of inducible NO synthase could contribute to the hypotension observed during septic shock $[28,30]$. 
We recently reported that purified rabbit LBP significantly enhanced NO production by murine bone marrow-derived macrophages stimulated with LPS plus IFN- $\gamma$ [9]. We have now examined the effects of $\mathrm{rBPI}_{23}$ on $\mathrm{NO}$ production (measured as $\mathrm{NO}_{2}^{-}$) using a homologous system in which murine macrophages were stimulated in the presence of NMP as a source of LBP and other plasma factors that might modulate LPS function.

\section{Materials and Methods}

Animals. CBA female mice were obtained from IFFACREDO (Saint Germain-sur-l'Arbresle, France) and used at 5-10 weeks of age.

Reagents. A recombinant $\mathrm{NH}_{2}$-terminal fragment of $\mathrm{BPI}$ $\left(\mathrm{rBPI}_{23}\right)$ was obtained from XOMA (Berkeley, CA). rIFN- $\gamma$ (lot no. 2309-24. produced by Genentech. South San Francisco) was supplied by Boehringer Ingelheim (Vienna). Polymyxin B, phenol-extracted LPS, and fluorescein-labeled LPS (FITC-LPS) from Escherichia coli O111 were purchased from Sigma (St. Louis). Recombinant human TNF $\alpha$ was a gift from BASF/ Knoll (Ludwigshafen. Germany). Polyclonal antibody to purified murine LBP was raised in rabbits and purified by protein $A$ affinity chromatography as previously described [11]. High-titered rabbit polyclonal antibody to E. coli O1I1 LPS was obtained by intravenous injection of heat-killed stationary phase bacteria $\left(5 \times 10^{9}\right.$ three times weekly for 2 weeks). Pooled heatinactivated $\left(56^{\circ} \mathrm{C}, 30 \mathrm{~min}\right)$ serum was stored at $-20^{\circ} \mathrm{C}$ until use. Preimmune normal rabbit serum and purified $\operatorname{IgG}$ served as control antibodies.

Macrophage cultures. Macrophages were obtained by in vitro differentiation of bone marrow precursor cells [3I]. Day 10 or 11 macrophages were detached by pipetting, suspended in Dulbecco's MEM (DMEM; Seromed. Munich) supplemented with $10 \%$ fetal calf serum (FCS; Seromed), and distributed in 96-well microculture plates $(75,000 /$ well $)$.

Infection of macrophage cultures. Macrophages were infected with Leishmania enriettii promastigotes as previously described [32] at a parasite-to-macrophage ratio of 16:1.

Macrophage activation. Infected or noninfected macrophages were washed with Hanks' balanced salt solution to remove serum and then cultured overnight with IFN- $\gamma$ plus LPS or TNF $\alpha$ in the presence or absence of $\mathrm{rBPI}_{23}$ or $1 \%$ pooled NMP or both. Alternatively, macrophages were primed with 10 units/ $\mathrm{mL} \mathrm{IFN-} \gamma$ for $24 \mathrm{~h}$ prior to stimulation with LPS (with or without $\mathrm{rBPI}{ }_{23}$ ) for an additional $24 \mathrm{~h}$.

TNF assay. Secretion of TNF was determined by biologic assay of supernatants collected $4 \mathrm{~h}$ after addition of LPS [33]. WEHI 164 clone 13 cells in 10\% FCS-supplemented RPMI medium $(10,000$ cells $/ 90 \mu \mathrm{L})$ were added to microtiter wells containing $90 \mu \mathrm{L}$ of serial dilutions of test supernatant or standard rTNF $\alpha$. Plates were incubated at $37^{\circ} \mathrm{C}$ for $48 \mathrm{~h} ; 20 \mu \mathrm{L}$ of $3-(1,4$ dimethylthiazol-2-yl)-2.5-diphenyl tetrazolium bromide (MTT; United States Biochemicals. Cleveland; $5 \mathrm{mg} / \mathrm{mL}$ in RPMI medium) was then added. After $4 \mathrm{~h}$ at $37^{\circ} \mathrm{C}$, supernatants were removed. and reduced dye was solubilized with $0.2 \mathrm{~mL}$ of 20 $\mathrm{m} M \mathrm{HCl}$ in isopropanol containing 3\% SDS. Optical density was
Table 1. Inhibition of lipopolysaccharide (LPS)-elicited tumor necrosis factor- $\alpha$ (TNF $\alpha$ ) production by recombinant (r) $\mathrm{BPI}_{23}$.

\begin{tabular}{lccc}
\hline & \multicolumn{3}{c}{ TNF units/mL } \\
\cline { 2 - 4 } LPS $(\mathrm{ng} / \mathrm{mL})$ & Control & BPI & PB \\
\hline 3 & 2 & $0^{*}$ & 0 \\
10 & 8 & 0 & 0 \\
30 & 20 & 5 & 0 \\
500 & 12 & 10 & 5 \\
\hline
\end{tabular}

NOTE. $\mathrm{BPI}_{23}$ or polymyxin $\mathrm{B}(\mathrm{PB}), 1 \mu \mathrm{g} / \mathrm{mL} .50 \%$ inhibition was obtained with 0.08 units/mL TNF $\alpha$. Results are average of duplicate supernatants and represent 4 independent experiments.

* Undetectable in 1:5 dilutions of macrophage supernatant (<0.4 units/ $\mathrm{mL})$.

determined at $570 \mathrm{~nm}$ using a microELISA reader fitted with a 620-nm reference filter. Preliminary experiments demonstrated that $\mathrm{rBPI}_{23}$ at the concentrations added to macrophage cultures had no effect on WEHI target cell viability either in the presence or absence of TNF $\alpha$ (data not shown).

$\mathrm{NO}_{2}^{-}$release. Twenty-four-hour macrophage supernatants $(100 \mu \mathrm{L})$ were assayed for $\mathrm{NO}_{2}^{-}$by the Griess reaction according to a recently described microassay [34]. Briefly, an equal volume of Griess reagent ( $1 \%$ sulphanilamide/0.1\% naphthylethylenediamine dihydrochloride $/ 2.5 \% \mathrm{H}_{3} \mathrm{PO}_{4}$ ) was incubated with macrophage supernatants for $10 \mathrm{~min}$ at room temperature, and absorbance was measured at $550 \mathrm{~nm}$ in a microELISA reader using a $620-\mathrm{nm}$ reference filter. $\mathrm{NO}_{2}^{-}$concentration (nmol/well) was determined using $\mathrm{NaNO}_{2}$ as a standard. The $\mathrm{SE}$ of replicate determinations was $<10 \%$.

Measurement of intracellular parasite killing. After a 24-h incubation in the presence or absence of various activators, macrophages were lysed by exposure to $0.01 \%$ SDS as described [32]. The wells were then supplemented with DMEM plus FCS and hemin, and parasite growth was recorded by measuring $\left[{ }^{3} \mathrm{H}\right]-$ thymidine incorporation [32].

Fluorescence-activated cell sorting analysis of LPS binding. Binding of fluoresceinated LPS was determined as previously described [8]. Macrophages $\left(10^{6} / \mathrm{mL}\right.$ of RPMI containing $4 \%$ bovine serum albumin and $1 \%$ NMP) were incubated with 10 or $100 \mathrm{ng}$ of FITC-LPS in the presence or absence of $\mathrm{rBPl}_{23}$ for 60 $\min$ at $37^{\circ} \mathrm{C}$. Cells were then washed twice with cold PBS and resuspended in RPMI $\left(10^{6} / \mathrm{mL}\right)$. Macrophage fluorescence was analyzed using FACScan (Becton Dickinson, Mountain View. CA) flow cytometry.

\section{Results}

Inhibition of LPS-elicited TNF production by $\mathrm{rBPI}_{23}$. Previous studies showed that purified or recombinant BPI inhibits LPS-elicited TNF production by human peripheral blood mononuclear cells or whole blood cultures $[18,20]$. We therefore examined the ability of $\mathrm{rBPI}_{23}$ to inhibit TNF production by the murine bone marrow-derived cultures to be used in studies of NO induction. As shown in table I, I 
Table 2. Inhibition of macrophage $\mathrm{NO}_{2}^{-}$production by recombinant (r) $\mathrm{BPI}_{23}$ is specific for lipopolysaccharide (LPS)-induced activation.

\begin{tabular}{|c|c|c|}
\hline & \multicolumn{2}{|c|}{$\mathrm{NO}_{2}{ }^{-}(\mathrm{nmol} / \mathrm{well})$} \\
\hline & Alone & Plus $\mathrm{rBPI}_{2}$ \\
\hline \multicolumn{3}{|l|}{$1 \% \mathrm{NMP}$} \\
\hline \multicolumn{3}{|l|}{ IFN $-\gamma$} \\
\hline 3 units $/ \mathrm{mL}+$ LPS. $10 \mathrm{ng} / \mathrm{mL}$ & 3.3 & 0.7 \\
\hline \multicolumn{3}{|l|}{100 units $/ \mathrm{mL}+$} \\
\hline $\mathrm{LPS}, 1 \mathrm{ng} / \mathrm{mL}$ & 5.9 & 0.4 \\
\hline $\mathrm{TNF} \alpha, 1000$ units $/ \mathrm{mL}$ & 2.1 & 2.0 \\
\hline \multicolumn{3}{|l|}{ No NMP } \\
\hline \multicolumn{3}{|l|}{ IFN- $\gamma$} \\
\hline 3 units $/ \mathrm{mL}+\mathrm{LPS}, 10 \mathrm{ng} / \mathrm{mL}$ & 0.6 & 0 \\
\hline \multicolumn{3}{|l|}{100 units $/ \mathrm{mL}+$} \\
\hline LPS. $1 \mathrm{ng} / \mathrm{mL}$ & 0.4 & 0 \\
\hline $\mathrm{TNF} \alpha, 1000$ units $/ \mathrm{mL}$ & 2.0 & 1.9 \\
\hline
\end{tabular}

NOTE. $\mathrm{rBPI}_{23}, 3 \mu \mathrm{g} / \mathrm{mL}$. Nitrite $\left(\mathrm{NO}_{2}^{-}\right)$represents mean of triplicate wells (SE, $\leqslant 0.1 \mathrm{nmol} /$ well). Interferon- $\gamma$ (IFN- $\gamma$ ) alone, $<0.1 \mathrm{nmol}$ of $\mathrm{NO}_{2}^{-} /$well. Data are from a typical experiment and represent 4 independent experiments. NMP. normal mouse plasma: TNF $\alpha$, tumor necrosis factor- $\alpha$.

$\mu \mathrm{g} / \mathrm{mL} \mathrm{rBPI}{ }_{23}$ effectively inhibited TNF secretion induced by 3 or $10 \mathrm{ng} / \mathrm{mL}$ LPS in the presence of $1 \%$ NMP. This inhibition was overcome at higher LPS concentrations. LPS activity was also inhibited by polymyxin B at $1 \mu \mathrm{g} / \mathrm{mL}$. TNF was undetectable in control untreated cultures (not shown).

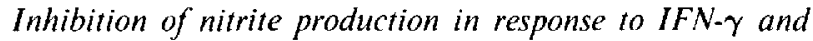
$L P S$. We then determined if $\mathrm{rBPI}_{23}$ could inhibit NO synthesis (measured as $\mathrm{NO}_{2}^{-}$) by murine macrophages under conditions similar to those described above for TNF production. Since LPS alone is a relatively poor stimulus for $\mathrm{NO}_{2}^{-}$ production, macrophages were cultured with LPS plus IFN- $\gamma$ as a priming signal. $\mathrm{NO}_{2}^{-}$release elicited by IFN- $\gamma$ plus LPS was much higher in the presence of 1\% NMP than in the plasma-free cultures (table 2). Increasing the concentration of NMP did not further promote $\mathrm{NO}_{2}^{-}$production under these conditions (data not shown). Addition of $1 \mu \mathrm{g} / \mathrm{mL}$ $\mathrm{rBPI}_{23}$ effectively inhibited $\mathrm{NO}_{2}^{-}$production in the presence or absence of plasma. To ensure that the inhibitory effect of $\mathrm{rBPI}_{23}$ was specific, macrophages were alternatively stimulated with IFN- $\gamma$ plus $\mathrm{TNF} \alpha$. $\mathrm{NO}_{2}^{-}$release elicited by IFN- $\gamma$ plus TNF $\alpha$ was independent of the presence of plasma and was not inhibited by $\mathrm{rBPI}_{23}$ (table 2 ). These results demonstrate that $\mathrm{rBPI}_{23}$ did not exert nonspecific toxicity or inhibitory effects on murine bone marrow-derived macrophages resulting in failure to induce NO synthetic capacity. Moreover, no differences were seen in the amount of cell-associated protein in each well at the end of the incubation (not shown), further evidence that $\mathrm{rBPI}_{23}$ was not toxic for these cultures.

Figure 1 presents the dose-dependency of the $\mathrm{rBPI}_{23}$ effect. For these experiments, macrophages were primed with IFN- $\gamma$ for $24 \mathrm{~h}$, extensively washed, and then stimulated with LPS in the presence of $1 \%$ NMP with or without $\mathrm{rBPI}_{23}$. Halfmaximal inhibition was obtained with $0.1-0.3 \mu \mathrm{g} / \mathrm{mL} \mathrm{rBPI}_{23}$ and nearly complete inhibition with $0.5 \mu \mathrm{g} / \mathrm{mL}$. With a $10-$ fold higher concentration of LPS $(100 \mathrm{ng} / \mathrm{mL}), 1 \mu \mathrm{g} / \mathrm{mL}$ $\mathrm{rBPI}_{23}$ still inhibited $\mathrm{NO}_{2}^{-}$production by $>50 \%$ (not shown).

Inhibition of $\mathrm{NO}_{2}^{-}$production by antibody to $L B P$. The ability of $\mathrm{rBPI}_{23}$ to inhibit macrophage activation by LPS may depend in part upon its capacity to compete with plasma LBP. NMP contains $\sim 2 \mu \mathrm{g} / \mathrm{mL}$ LBP as determined
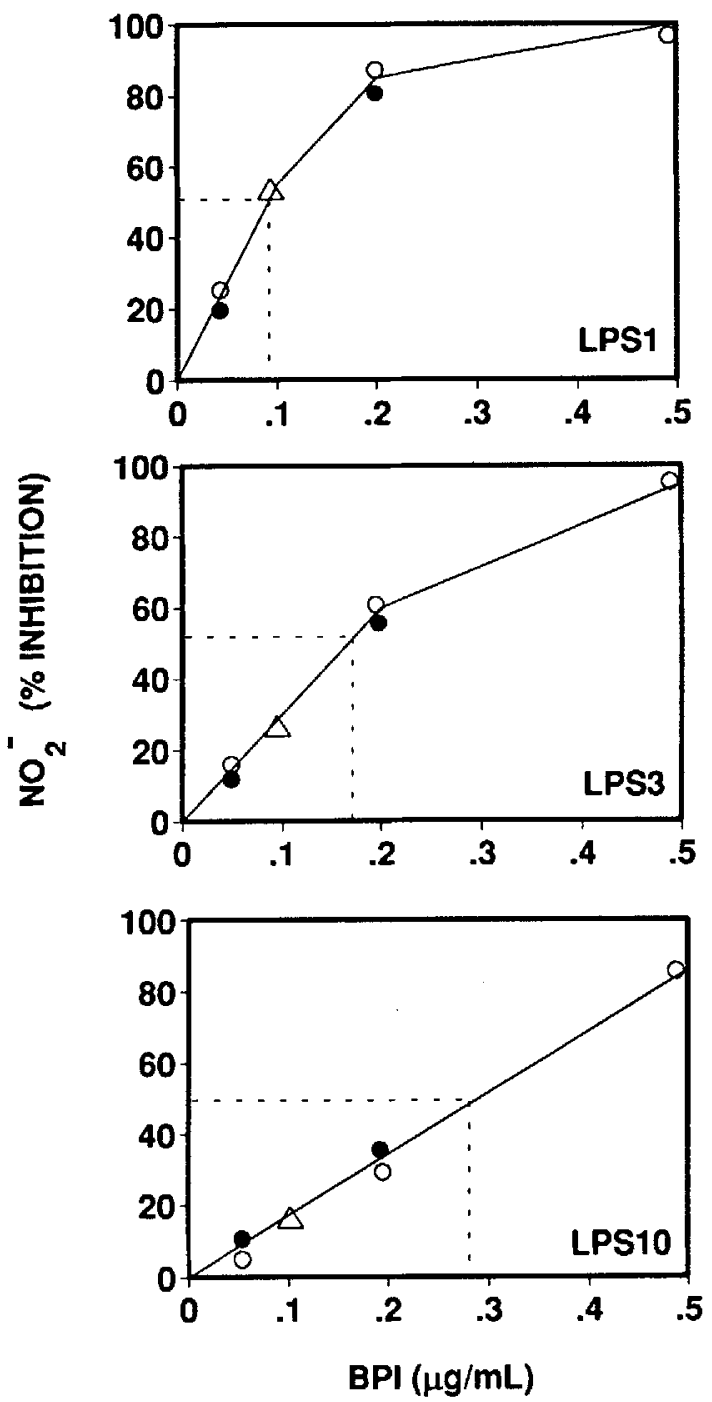

Figure 1. Dose-dependent inhibition by recombinant (r) $\mathrm{BPI}_{23}$ of lipopolysaccharide (LPS)-elicited nitrite $\left(\mathrm{NO}_{2}^{-}\right)$production. Interferon- $\gamma$-primed macrophages were washed and stimulated with 1,3 , or $10 \mathrm{ng} / \mathrm{mL}$ LPS and $1 \%$ normal mouse plasma immediately after addition of various concentrations of $\mathrm{rBPI}_{23}$. Each point represents \% inhibition of control $\mathrm{NO}_{2}^{-}$release in absence of $\mathrm{rBPI}_{23}$ calculated as mean of three determinations. Data are from three independent experiments $(0, \bullet, \Delta)$. Absolute nmol/well $\mathrm{NO}_{2}^{-}$release in control cultures (mean of three experiments \pm SE): $1 \mathrm{ng} / \mathrm{mL} \mathrm{LPS}$, $1.0 \pm 0.1 ; 3 \mathrm{ng} / \mathrm{mL}$ LPS, $2.0 \pm 0.2 ; 10 \mathrm{ng} / \mathrm{mL}$ LPS, $4.0 \pm 0.7$. 
Table 3. Inhibition of lipopolysaccharide (LPS)-dependent $\mathrm{NO}_{2}^{-}$ production by anti-LPS-binding protein (LBP) and anti-LPS.

\begin{tabular}{lcccc}
\hline & \multicolumn{4}{c}{ \% inhibition of $\mathrm{NO}_{2}^{-}$production } \\
\cline { 2 - 5 } & LPS 1 & LPS 3 & LPS 10 & TNF $\alpha$ \\
\hline \multirow{2}{*}{ Anti-LPS } & 100 & ND & 89 & 7 \\
& ND & 100 & 87 & 0 \\
Anti-LBP & 100 & 97 & 83 & 0 \\
& 88 & 27 & ND & 0 \\
& 79 & 32 & ND & 0 \\
\hline
\end{tabular}

NOTE. LPS. $1-10 \mathrm{ng} / \mathrm{mL}$; tumor necrosis factor- $\alpha$ (TNF $\alpha)$. 1000 units/ $\mathrm{mL}$ in the presence of 100 units $/ \mathrm{mL}$ interferon- $\gamma$ (IFN- $\gamma$ ): anti-LPS $(1: 500$ dilution), anti-LBP $(400 \mu \mathrm{g} \mathrm{IgG} / \mathrm{mL})$. Absolute nmol/well nitrite $\left(\mathrm{NO}_{2}^{-}\right)$in control cultures (mean $\pm S E$ ): LPS 1, $0.7 \pm 0.1 ;$ LPS 3, 2.1 \pm 0.2 ; LPS 10 . $3.8 \pm 0.1:$ IFN- $\gamma / T N F \alpha, 1.9 \pm 0.3$. ND. not determined

by RIA (unpublished data). The recent availability of purified polyclonal antibody directed against murine LBP [11] allowed us to examine its effect on $\mathrm{NO}_{2}^{-}$production stimulated by LPS in the presence of $1 \%$ NMP using IFN- $\gamma-$ primed macrophages.

Macrophages were alternatively stimulated with TNF $\alpha$ plus IFN- $\gamma$, and rabbit polyclonal antiserum directed against E. coli O111 LPS was used as a positive control for inhibition of LPS-dependent stimulation. Anti-LPS (three experiments) inhibited $\mathrm{NO}_{2}^{-}$production elicited by LPS but not by IFN- $\gamma /$ TNF $\alpha$ (table 3). In two experiments, anti-LBP similarly inhibited only LPS-induced $\mathrm{NO}_{2}^{-}$release. No inhibition was observed with normal rabbit serum or purified preimmune rabbit IgG (data not shown). These results are consistent with the NMP-dependent enhancement of $\mathrm{NO}_{2}^{-}$release as well as with results from a previous study [9], demonstrating that purified rabbit LBP enhances $\mathrm{NO}_{2}^{-}$production by LPS-stimulated murine macrophages.

Inhibition of LPS-mediated $\mathrm{NO}_{2}^{-}$production as a function of time of $\mathrm{rBPI}_{23}$ addition. The effect of time of $\mathrm{rBPI}_{23}$ addition on its inhibition of NO production was examined using IFN- $\gamma$-primed macrophages. $\mathrm{rPPI}_{23}$ strongly inhibited $\mathrm{NO}_{2}^{-}$ release when added up to $\mathrm{I} \mathrm{h}$ after $\mathrm{I}$ or $3 \mathrm{ng} / \mathrm{mL}$ LPS plus $\mathrm{I} \%$ NMP (figure 2). Moreover, $\mathrm{rBPI}_{23}$ consistently inhibited the response to $1 \mathrm{ng} / \mathrm{mL}$ LPS even when added as late as $4 \mathrm{~h}$. Induction of NO synthesis appeared to be an even slower process in the absence of plasma since inhibition of $3 \mathrm{ng} / \mathrm{mL}$ LPS was obtained when $\mathrm{rBPI}_{23}$ was added $8 \mathrm{~h}$ after LPS (data not shown). When the concentration of LPS was increased to $10 \mathrm{ng} / \mathrm{mL}$ (1\% NMP), $\mathrm{rBPI}_{23}$ did not inhibit $\mathrm{NO}_{2}^{-}$release when added $30 \mathrm{~min}$ after stimulation (figure 2). We therefore examined the effects of delaying the addition of inhibitor for shorter periods. In three experiments, addition of $\mathrm{rBPI}_{23} 10 \mathrm{~min}$ after $10 \mathrm{ng} / \mathrm{mL}$ LPS inhibited $\mathrm{NO}_{2}^{-}$release by $40.7 \% \pm 4.2 \%$ (mean $\pm \mathrm{SE}$ ).

Inhibition of LPS binding to murine macrophages by $r B P I_{23}$. We previously reported that purified LBP or acute-

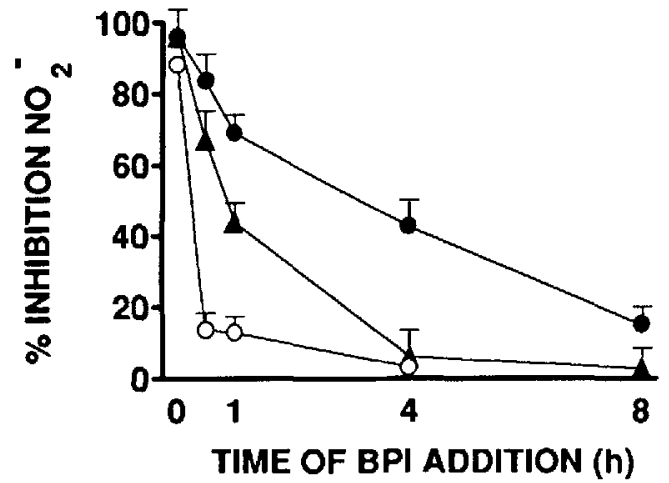

Figure 2. Inhibition of macrophage nitrite $\left(\mathrm{NO}_{2}^{-}\right)$production by recombinant (r) $\mathrm{BPl}_{23}$ added at various times after lipopolysaccharide (LPS) exposure. $\mathrm{rBPI}_{23}(1 \mu \mathrm{g} / \mathrm{mL})$ was added to primed macrophages at various times relative to addition of LPS at $1(\bullet), 3(4)$, or $10 \mathrm{ng} / \mathrm{mL}(\mathrm{O})$. Data are $\%$ inhibition of $\mathrm{NO}_{2}^{-}$production; each point represents mean $\pm \mathrm{SE}$ of at least three independent experiments. Absolute $\mathrm{nmol} /$ well $\mathrm{NO}_{2}^{-}$release in control cultures (mean of 3 or 4 experiments $\pm \mathrm{SE}$ ): $1 \mathrm{ng} / \mathrm{mL}$ LPS, $0.7 \pm 0.1 ; 3 \mathrm{ng} / \mathrm{mL}$ LPS, $2.2 \pm$ $0.3 ; 10 \mathrm{ng} / \mathrm{mL}$ LPS, $3.2 \pm 0.2$.

phase rabbit serum enhanced the binding of $1 \mu \mathrm{g} / \mathrm{mL}$ FITCLPS to bone marrow-derived macrophages [9]. Furthermore, anti-LBP inhibited LPS binding in the presence of rabbit or murine sera $[9,11]$. Since $\mathrm{NO}_{2}^{-}$production is induced by much lower levels of LPS than those used in the binding experiments, we have now examined the binding of 10 or $100 \mathrm{ng} / \mathrm{mL}$ FITC-LPS to bone marrow-derived macrophages using 1\% NMP. In addition, primed and unprimed macrophages were compared since both populations were used to study the effects of $\mathrm{rBPI}_{23}$ on NO production, and it was possible that IFN- $\gamma$ pretreatment might modify the expression of macrophage CD14 or other putative LPS receptor molecules. As shown in table 4, $1 \mu \mathrm{g} / \mathrm{mL} \mathrm{rBPI}_{23}$ strongly inhibited binding at either LPS concentration. Furthermore, virtually no differences were detectable between the primed and unprimed populations. Inasmuch as low but reproducible binding of $10 \mathrm{ng} / \mathrm{mL}$ LPS was detectable in these experi-

Table 4. Recombinant (r) $\mathrm{BPI}_{23}$ in hibition of lipopolysaccharide (LPS) binding by primed or unprimed murine macrophages.

\begin{tabular}{lcc}
\hline & \multicolumn{2}{c}{ Mean fluorescence (arbitrary units) } \\
\cline { 2 - 3 } Macrophage status, & ${\text { Without } \mathrm{rBPI}_{23}}$ With rBPI $_{23}$ \\
\hline UPS concentration $(\mathrm{ng} / \mathrm{mL})$ & & \\
$\quad 10$ & 5.2 & 2.6 \\
100 & 17.6 & 3.5 \\
Primed & & \\
10 & 5.2 & 2.6 \\
100 & 13.2 & 3.3 \\
\hline
\end{tabular}

NOTE. Binding in 4\% albumin (negative control) was 2.5-2.6 fluorescence units. 


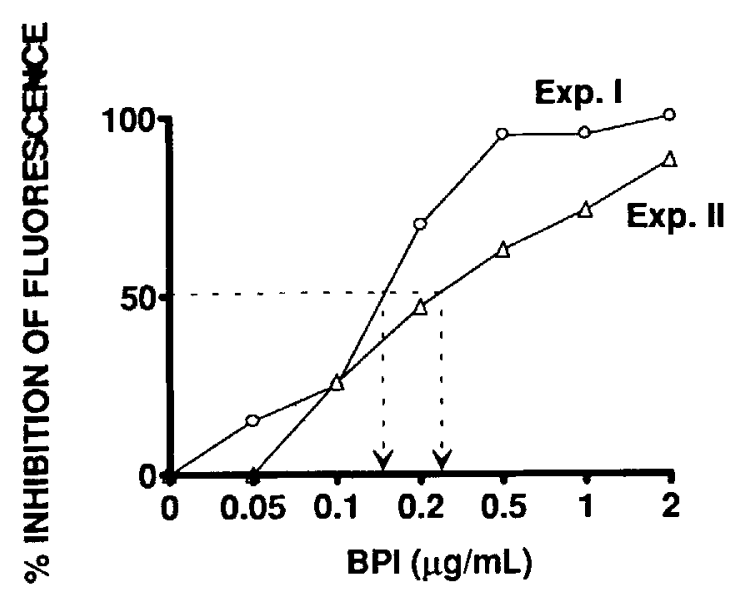

Figure 3. Dose-dependent inhibition of lipopolysaccharide (LPS) binding to murine macrophages by recombinant (r) $\mathrm{BPI}_{23}$. Interferon- $\gamma$-primed macrophages ( 10 units/mL, 24 h) were incubated with $10 \mathrm{ng} / \mathrm{mL}$ fluorescein isothiocyanate-LPS (FITC-LPS) and $1 \%$ normal mouse plasma with or without increasing concentrations of $\mathrm{rBPI}_{23}$ for $\mathrm{l} \mathrm{h}$ at $37^{\circ} \mathrm{C}$. LPS binding measured as FITCLPS fluorescence is presented as $\%$ of control binding in absence of $\mathrm{rBPI}_{23}$. Mean fluorescence (arbitrary units) of 10,000 cells in control: experiment $(\exp )$ I (O), 4.8; $\exp$ II $(\triangle), 4.7$.

ments, we could directly compare the capacity of $\mathrm{rBPI}_{23}$ to inhibit binding with its effect on $\mathrm{NO}_{2}^{-}$release. When binding of $10 \mathrm{ng} / \mathrm{mL}$ FITC-LPS was examined in the presence of $1 \%$ NMP (figure 3), half-maximal inhibition of macrophage fluorescence was obtained with $\sim 0.2 \mu \mathrm{g} / \mathrm{mL} \mathrm{rBPI}_{23}$ (i.e., concentrations similar to those for $\mathrm{NO}_{2}^{-}$production). To further examine the relationship between LPS binding and NO production, $\mathrm{rBPI}_{23}$ was added $10 \mathrm{~min}$ after $10 \mathrm{ng} / \mathrm{mL}$ FITC-LPS. In three experiments, delaying the addition of $\mathrm{rBPI}_{23}$ decreased the inhibition of macrophage fluorescence from $95.3 \% \pm 3.8 \%\left(\mathrm{rBPI}_{23}\right.$ at time 0$)$ to $29.0 \% \pm 4.4 \%\left(\mathrm{rBPI}_{23}\right.$ at $10 \mathrm{~min})$.

Inhibition of intracellular leishmanicidal activity. Since $\mathrm{rBPI}_{23}$ could inhibit the induction of $\mathrm{NO}_{2}^{-}$release, it was of interest to examine its effects on an in vitro system in which NO is known to have biologic activity. An excellent correlation exists between murine macrophage activation for NO production and the ability to kill intracellular Leishmania species [35-37]. We therefore examined the effects of $\mathrm{rBPI}_{23}$ on leishmanicidal activity stimulated by LPS. Macrophages infected with Leishmania species $24 \mathrm{~h}$ before stimulation generally produce higher levels of $\mathrm{NO}_{2}^{-}$than do uninfected cells (unpublished data). Addition of IFN- $\gamma$ plus LPS or IFN- $\gamma$ plus TNF $\alpha$ induced $\mathrm{NO}_{2}^{-}$secretion and leishmanicidal activity (table 5). In cultures stimulated with IFN- $\gamma$ and LPS, BPI inhibited $\mathrm{NO}_{2}^{-}$production and abolished intracellular killing. $\mathrm{rBPI}_{23}$ did not inhibit cytotoxic activity nonspecifically since intracellular killing induced by IFN- $\gamma$ plus TNF $\alpha$ was unaffected by $\mathrm{rBPI}_{23}$. Furthermore, the ability of control macrophages (DMEM or IFN- $\gamma$ alone) to support Leish- mania infection in the presence of $\mathrm{rBPI}_{23}$ is further evidence for the lack of toxicity of this molecule under the in vitro conditions used in this study.

\section{Discussion}

Production of a large array of cytokines and inflammatory mediators by LPS-activated macrophages undoubtedly contributes to the pathologic manifestations of gram-negative sepsis. In particular, current evidence suggests that rapid release of TNF $\alpha$ in response to picogram concentrations of LPS is responsible for many of the clinical symptoms associated with lethal endotoxemia [38]. However, high levels of serum TNF are not necessarily associated with mortality [39]. Circulating levels of IFN- $\gamma$ are also detectable in patients and in experimental models of endotoxic shock and, recently, we [40] and others [41, 42] have demonstrated that monoclonal antibodies to IFN- $\gamma$ can significantly decrease lethality in vivo.

As previously shown for macrophage cytolytic activity, efficient induction of NO production by either LPS or TNF $\alpha$ requires costimulation by IFN- $\gamma[26,34]$. Although it has been suggested that induction of the $\mathrm{Ca}^{2+}$-independent $\mathrm{NO}$ synthase pathway is important in the pathogenesis of endotoxic shock, recent attempts to correlate toxicity of bacterial products with enzyme induction in vivo have been unsuccessful $[43,44]$. Since in vivo models designed to test the

Table 5. Recombinant (r) $\mathrm{BP}^{2} \mathrm{I}_{23}$ inhibits intracellular leishmanicidal activity of bone marrow-derived macrophages stimulated by interferon (IFN)- $\gamma$ plus tipopolysaccharide (LPS).

\begin{tabular}{|c|c|c|c|}
\hline Experiment no., conditions & $\mathrm{rBPI}_{23}$ & $\begin{array}{l}\text { Parasite survival } \\
\quad(\mathrm{cpm} \pm \mathrm{SE})\end{array}$ & $\begin{array}{c}\mathrm{NO}_{2}^{-} \\
\text {(nmol/well) }\end{array}$ \\
\hline \multicolumn{4}{|l|}{ Experiment I } \\
\hline \multirow[t]{2}{*}{ DMEM } & - & $53,646 \pm 827$ & 0.1 \\
\hline & + & $55,066 \pm 130$ & 0.1 \\
\hline \multirow[t]{2}{*}{ IFN- $\gamma, 10$ units $/ \mathrm{mL}+$} & - & $61,392 \pm 2652$ & 0.4 \\
\hline & + & $57.426 \pm 573$ & 0.2 \\
\hline \multirow[t]{2}{*}{ L.PS, I ng/mL } & - & $374 \pm 95$ & 4.3 \\
\hline & + & $58,953 \pm 943$ & 0.2 \\
\hline \multirow[t]{2}{*}{ LPS, $3 \mathrm{ng} / \mathrm{mL}$} & - & $498 \pm 142$ & 6.5 \\
\hline & + & $57,060 \pm 40$ & 0.8 \\
\hline \multicolumn{4}{|l|}{ Experiment II } \\
\hline \multirow[t]{2}{*}{ DMEM } & - & $39,222 \pm 725$ & 0 \\
\hline & + & $42.940 \pm 522$ & 0 \\
\hline \multirow[t]{2}{*}{ IFN- $\gamma, 100$ units $/ \mathrm{mL}$} & - & $36.988 \pm 717$ & 0 \\
\hline & + & $42,623 \pm 630$ & 0 \\
\hline \multirow{2}{*}{$\begin{array}{l}\text { IFN- } \gamma, 10 \text { units } / \mathrm{mL}+\text { LPS, } \\
3 \mathrm{ng} / \mathrm{mL}\end{array}$} & - & $70 \pm 5$ & 6.5 \\
\hline & + & $47.351 \pm 992$ & 0.2 \\
\hline \multirow{2}{*}{$\begin{array}{l}\text { IFN- } \gamma, 100 \text { units } / \mathrm{mL}+\mathrm{TNF} \alpha \text {, } \\
1000 \text { units } / \mathrm{mL}\end{array}$} & - & $5456 \pm 176$ & 2.4 \\
\hline & + & $2647 \pm 302$ & 2.5 \\
\hline
\end{tabular}

NOTE. Data are from 2 independent experiments and represent 5 experiments. DMEM, Dulbecco's MEM; IFN- $\gamma$, interferon- $\gamma$; TNF $\alpha$, tumor necrosis factor $\alpha . \mathrm{rBPI}_{23}, \mathrm{l} \mu \mathrm{g} / \mathrm{mL}$. Nitrite $\left(\mathrm{NO}_{2}^{-}\right) . \mathrm{SE} \leqslant 0.3 \mathrm{nmol} / \mathrm{well}$ $(n=3)$. 
efficiency of BPI in inhibiting the lethal consequences of endotoxic shock should consider possible effects on NO production, we first assessed the capacity of $\mathrm{rBPI}_{23}$ to inhibit $\mathrm{NO}_{2}^{-}$ release by macrophages stimulated in vitro by IFN- $\gamma$ plus LPS or by IFN- $\gamma$ plus TNF $\alpha$.

Preliminary studies on LPS-elicited TNF secretion by bone marrow-derived macrophages demonstrated that $\mathrm{rBPI}_{23}$ inhibited release of this mediator at concentrations equivalent to those previously reported by Marra et al. [20] for human monocytes. In those studies, LPS was preincubated with purified BPI. In our experiments, LPS was added to cell cultures containing $\mathrm{rBPI}_{23}$ and $1 \% \mathrm{NMP}$ was immediately added. Using a similar protocol with IFN- $\gamma$-primed macrophages, we found that $\mathrm{rBPI}_{23}$ inhibited LPS-triggered NO production with an approximate $\mathrm{IC}_{50}$ of $0.1-0.3 \mu \mathrm{g} / \mathrm{mL}$ $(4-12 \mathrm{n} M)$. These concentrations are nearly identical to those reported by Ooi et al. [18] for the inhibition by an $\mathrm{NH}_{2}$-terminal BPI fragment of TNF secretion in whole blood elicited by $1 \mathrm{ng} / \mathrm{mL}$ LPS. Furthermore, on a molar basis, $\mathrm{rBPI}_{23}$ was at least as effective as polymyxin B (data not shown), in agreement with results of Marra et al. [20] on effects of polymyxin $\mathrm{B}$ and soluble $\mathrm{BPI}$ on in vivo induction of TNF $\alpha$ secretion. When we later examined the effect of $\mathrm{rBPI}_{23}$ on macrophage binding of FITC-LPS, half-maximal inhibition was observed at concentrations similar to those obtained for inhibition of NO production. These concentrations are also similar to the reported $K_{\mathrm{d}}$ of $\mathrm{rBPI}_{23}$ for various LPS [21].

As shown in control experiments, $\mathrm{NO}_{2}^{-}$production elicited by IFN- $\gamma$ plus TNF $\alpha$ is unaffected by $\mathrm{rBPI}_{23}$, demonstrating specificity for LPS-activated macrophages. Of note, under the conditions used in these studies (i.e., low IFN- $\gamma$ and LPS concentrations and assay of $\mathrm{NO}_{2}^{-}$at $24 \mathrm{~h}$ ). TNF is not an important cofactor for LPS-induced NO production. The amount of bone marrow macrophage TNF secreted is much less than the concentrations used here to trigger NO production (these studies and [9]). Furthermore, antibody to murine TNF $\alpha$ did not inhibit $\mathrm{NO}_{2}^{-}$production by cultures stimulated with IFN- $\gamma$ plus LPS [45].

Interestingly, $\mathrm{rBPI}_{23}$ inhibited $\mathrm{NO}_{2}^{-}$production when added several hours after LPS. Similar results were obtained with polymyxin B or rabbit anti-O111 LPS (not shown). Elicitation of NO production is a relatively slow process, with $\mathrm{NO}_{2}^{-}$release first detectable $4-8 \mathrm{~h}$ after stimulation. Our results demonstrate that induction occurs more quickly at 10 $\mathrm{ng} / \mathrm{mL}$ LPS than at a 10 -fold lower concentration, suggesting that low concentrations of LPS stimulate certain macrophage responses such as NO synthase activity by a slow accumulation of multiple signal-transducing events. The ability of $\mathrm{rBPI}_{23}$ to inhibit NO production when added after LPS contrasts with our previous results on inhibition of TNF production by human monocytes [23]. It remains to be seen whether LPS recognition and signal-transduction events leading to NO production and TNF $\alpha$ secretion are significantly different.
Alternatively, plasma or cellular components involved in LPS-dependent macrophage activation may vary between the human and murine systems. As shown here, antibody to murine plasma LBP inhibited $\mathrm{NO}_{2}^{-}$release, consistent with our previous results using purified LBP [9]. However, it is also clear that NO production elicited by higher LPS concentrations can occur in the absence of plasma or plasma LBP. Furthermore, $\mathrm{rBPI}_{23}$ inhibits $\mathrm{NO}_{2}^{-}$release in the presence or absence of NMP, and thus of LBP.

$\mathrm{rBPI}_{23}$ also inhibited macrophage leishmanicidal activity induced by IFN- $\gamma$ plus LPS but not by IFN- $\gamma$ plus TNF $\alpha$. These experiments underline the specificity of $\mathrm{HBPI}_{23}$ for LPS and provide a sensitive in vitro model to demonstrate lack of toxicity for macrophages since control unstimulated cells support an intracellular microbial infection equally well in the presence or absence of $\mathrm{rBPI}_{23}$.

Taken together, these results suggest that $\mathrm{rBPl}_{23}$ might be an effective inhibitor of NO production in vivo where concentrations of LPS rarely exceed picogram per milliliter levels $[46,47]$. Moreover, inhibition of LPS-elicited TNF production by $\mathrm{rBPI}_{23}$ could provide a further level of control of inducible NO synthase activity in gram-negative shock. The relative role of this pathway in patients or in murine models of endotoxemia remains a controversial issue that deserves further study.

\section{References}

1. Glauser MP. Zanetti G. Baumgartner JD. Cohen J. Septic shock: pathogenesis. Lancet 1991:338:732-9.

2. Morrison DC. Ryan JL. Bacterial endotoxins and host immune responses. Adv Immunol 1979:28:293-450.

3. Tobias PS, Mathison JC. Ulevitch RJ. A family of lipopolysaccharide binding proteins involved in responses to gram-negative sepsis. J Biol Chem 1988;263:13479-81.

4. Tobias PS, Soldau K. Ulevitch RJ. Isolation of a lipopolysaccharidebinding acute phase reactant from rabbit serum. I Exp Med 1986:164:777-93.

5. Tobias PS, Soldau K, Ulevitch RJ. Identification of a lipid A binding site in the acute phase reactant lipopolysaccharide binding protein. J Biol Chem 1989;264:10867-71.

6. Wright SD, Ramos RA, Tobias PS, Ulevitch RJ, Mathison JC. CD14, a receptor for complexes of lipopolysaccharide (LPS) and I.PS binding protein. Science 1990;249:1431-3.

7. Schumann RR, Leong SR, Flaggs GW, et al. Structure and function of lipopolysaccharide binding protein. Science 1990;249:1429-31.

8. Heumann D, Gallay P, Barras C, et al. Control of lipopolysaccharide (LPS) binding and LPS-induced tumor necrosis factor secretion in human peripheral blood monocytes. J Immunol 1992; 148:3505-12.

9. Betz Corradin S, Mauël J, Gallay P. Heumann D, Ulevitch RJ, Tobias PS. Enhancement of murine macrophage binding of and response to bacterial lipopolysaccharide (LPS) by LPS-binding protein. J Leukoc Biol 1992:52:363-8.

10. Mathison JC, Tobias PS. Wolfson E, Ulevitch RJ. Plasma lipopolysaccharide binding protein: a key component in macrophage recognition of gram-negative lipopolysaccharide (LPS). J Immunol 1992:49:200-6.

11. Gallay P, Carrel S. Glauser MP, et al. Purification and characterization of murine LPS-binding protein. Infect Immun 1993;61:378-83.

12. Lee JD. Kato K, Tobias PS, Kirkland TN, Ulevitch RJ. Transfection of 
CD14 into 70Z/3 cells dramatically enhances the sensitivity to complexes of lipopolysaccharide (LPS) and LPS binding protein. J Exp Med 1992;175:1697-705.

13. Weiss J. Elsbach P. Olson I. Odeberg H. Purification and characterization of a potent bactericidal and membrane active protein from the granules of human polymorphonuclear leukocytes. J Biol Chem 1978:253:2664-72

14. Weiss J. Olsson I. Cellular and subcellular localization of the bacterial/ permeability-increasing protein of neutrophils. Blood 1987:69: $652-9$.

15. Mannion BA, Kalatzis ES, Weiss J, Elsbach P. Preferential binding of the neutrophil cytoplasmic granule-derived bactericidal/ permeability increasing protein to target bacteria. Implications and use as a means of purification. J Immunol 1989:42:2807-12.

16. Weiss J. Elsbach P. Shu C. et al. Human bactericidal/permeabilityincreasing protein and a recombinant $\mathrm{NH}_{2}$-terminal fragment cause killing of serum-resistant gram-negative bacteria in whole blood and inhibit tumor necrosis factor release induced by the bacteria. J Clin Invest 1992:90:1122-30.

17. Gray PW. Flaggs G. Leong SR, et al. Cloning of the cDNA of a human neutrophil bactericidal protein. Structural and functional correlations. J Biol Chem 1989;264:9505-9.

18. Ooi CE. Weiss J. Doerfler ME. Elsbach P. Endotoxin-neutralizing properties of the $25 \mathrm{kD}$ bactericidal/permeability increasing protein of human neutrophils. J Exp Med 1991:174:649-55.

19. Marra MN. Wilde CG. Griffith JE. Snable JL. Scott RW. Bactericidal/ permeability-increasing protein has endotoxin-neutralizing activity. J Immunol 1990:144:662-6.

20. Marra MN. Wilde CG, Collins MS, Snable JL. Thornton MB, Scott $\mathrm{RW}$. The role of bactericidal/permeability-increasing protein as a natural inhibitor of bacterial endotoxin. J Immunol 1992;148: $532-7$.

21. Gazzano-Santoro H. Parent JB, Grinna L. et al. High-affinity binding of the bactericidal/permeability-increasing protein and a recombinant amino-terminal fragment to the lipid A region of lipopolysaccharide. Infect Immun 1992;60:4754-61

22. Mézaros K. Parent JB, Gazzano-Santoro H, et al. A recombinant amino terminal fragment of bactericidal/permeability increasing protein inhibits the induction of leukocyte responses by LPS. J Leukoc Biol (in press).

23. Heumann D. Gallay P. Betz Corradin S. Barras C. Baumgartner JD, Glauser MP. Competition between bactericidal/permeability-increasing protein and lipopolysaccharide-binding protein for lipopolysaccharide binding to monocytes. J Infect Dis 1993:167:1351-7.

24. Pace JL. Russell SW. Activation of mouse macrophages for tumor cell killing. I. Quantitative analysis of interactions between lymphokine and lipopolysaccharide. J Immunol 1981:126:1863-7.

25. Nacy CA. Oster CN. James SL. Meltzer MS. Activation of macrophages to kill rickettsiae and leishmania: dissociation of intracellular microbicidal activities and extracellular destruction of neoplastic and helminth targets. Contemp Top Immunobiol 1984:13: 147-70.

26. Stuehr DJ. Marletta MA. Induction of nitrite/nitrate synthesis in murine macrophages by BCG infection, lymphokines, or interferon- $\gamma . \mathbf{J}$ Immunol 1987:139:518-25.

27. Maü̈] J. Buchmüller-Rouiller Y. Effect of lipopolysaccharide on intracellular killing of Leishmania enrienii and correlation with macrophage oxidative metabolism. Eur J Immunol 1987;17:203-8.

28. Moncada S, Palmer RMJ, Higgs EA. Nitric oxide: physiology, pathophysiology, and pharmacology. Pharmacol Rev 1991:43:109-42.

29. Nathan C. Nitric oxide as a secretory product of mammalian cells. FASEB J 1992:6:3051-64.

30. Petros A. Bennett D. Vallance P. Effect of nitric oxide synthase inhibi- tors on hypotension in patients with septic shock. Lancet 1991; $338: 1557-8$

31. Kelso A, Glasebrook AL, Kanagawa O, Brunner KT. Production of macrophage-activating factor by $\mathrm{T}$ lymphocyte clones and correlation with other lymphokine activities. J Immunol 1982:129:550-6.

32. Mauël $\mathbf{J}$. Intracellular parasite killing induced by electron carriers. $I$. Effect of electron carriers on intracellular Leishmania spp. in macrophages from different genetic backgrounds. Mol Biochem Parasitol 1984:13:83-96.

33. Espevik T, Nissen-Meyer J. A highly sensitive cell line, WEHI 164 clone 13, for measuring cytotoxic factor/tumor necrosis factor from human monocytes. J Immunol Methods 1986;95:99-105.

34. Ding AH, Nathan CF, Stuehr DJ. Release of reactive nitrogen intermediates and reactive oxygen intermediates from mouse peritoneal macrophages. Comparison of activating cytokines and evidence for independent production. J Immunol 1988;141:2407-12.

35. Liew FY, Li Y, Millott SJ. TNF $\alpha$ synergizes with IFN $\gamma$ in mediating killing of Leishmania najor through the induction of nitric oxide. $\mathrm{J}$ Immunol 1990;145:4306-11.

36. Green SJ, Crawford RM, Hockmeyer JT, Meltzer MS, Nacy CA. Activated macrophages destroy intracellular Leishmania major amastigotes by an L-arginine-dependent killing mechanism. J Immunol 1990;144:278-83.

37. Mauël J. Ransijn A. Buchmüller-Rouiller Y. Killing of Leishnania parasites in activated murine macrophages is based on an L-argininedependent process that produces nitrogen derivatives. J Leukoc Biol 1991:49:73-82.

38. Tracey KJ, Lowry S. The role of cytokine mediators in septic shock. Adv Surg 1990;23:21-56.

39. Zanetti G, Heumann D. Gérain J, et al. Cytokine production after intravenous or peritoneal gram-negative bacterial challenge in mice Comparative protective efficacy of antibodies to tumor necrosis factor- $\alpha$ and to lipopolysaccharide. J Immunol 1992;148:1890-7.

40. Kohler J, Heumann D, Garotta G, et al. IFN $\gamma$ involvement in the severity of gram-negative infections in mice. J Immunol 1993:151: 916-21.

41. Billau A. Gamma-interferon: the match that lights the fire? Immunol Today 1988;9:37-40.

42. Doherty JA, Lange JR, Langstein HN, Alexander HR, Buresh CM. Norton JA. Evidence for IFN- $\gamma$ as a mediator of the lethality of endotoxin and tumor necrosis factor- $\alpha$. J Immunol 1992:149:166670.

43. Evans T. Carpenter A. Silva A. Cohen J. Differential effects of monoclonal antibodies to tumor necrosis factor alpha and gamma interferon on induction of hepatic nitric oxide synthase in experimental gramnegative sepsis. Infect Immun 1992;60:4133-9.

44. Palacios M. Knowles RG, Moncada S. Enhancers of nonspecific immunity induce nitric oxide synthase: induction does not correlate with toxicity or adjuvancy. Eur J Immunol 1992:22:2303-7.

45. Betz Corradin S, Buchmüller-Rouiller Y, Mauël J. Phagocytosis enhances murine macrophage activation by interferon- $\gamma$ and tumor necrosis factor- $\alpha$. Eur J Immunol 1991;2 1:2552-8.

46. Brandizaeg P. Kierulf P. Gaustad P. Dobloug J, Molines TE, Sirnes K. Systemic meningococcal disease: a model infection to study acute endotoxemia in man. In: Levin J, Büller HR, ten Cate JW, van Deventer S.JH. Sturk A. eds. Bacterial endotoxins: pathophysiological effects, clinical significance, and pharmacological control. New York: Alan R Liss, 1988:263-71.

47. van Deventer SJH, de Vries I, Statius LW, et al. Endotoxemia, bacterernia and urosepsis. In: Levin J, Büller HR, ten Cate JW, van Deventer SJH, Sturk A, eds. Bacterial endotoxins: pathophysiological effects, clinical significance, and pharmacological control. New York: Alan R Liss, 1988:213-24. 